\title{
VALUE BASED HEALTHCARE - PRINCIPLES AND RECOMMENDATIONS FOR ORGANIZATIONAL SOLUTIONS IN POLAND
}

\author{
VALUE BASED HEALTHCARE - ZASADY I REKOMENDACJE DLA ROZWIĄZAŃ \\ ORGANIZACYJNYCH W POLSCE
}

\author{
National Institute of Public Health - National Institute of Hygiene \\ Department of System and Economic Analyses \\ Narodowy Instytut Zdrowia Publicznego- Państwowy Zakład Higieny \\ Zakład Analiz Ekonomicznych i Systemowych,
}

\begin{abstract}
OBJECTIVE. The aim of this paper is is to present the assumptions of the Value Based Healthcare concept, the related benefits and examples of countries in which the concept is implemented. The article also proposes solutions based on the VBHC model that could be implemented in the Polish healthcare system.

MATERIALS AND METHODS. A literature search was conducted using the PubMed via Ovid database using the following keywords: Gray literature items were also analyzed using the Google Scholar tool and other documents, eg of the European Commission. Then the work was divided into the following thematic areas: definitions and principles of VBHC, benefits and challenges related to the implementation of the model, VBHC in Europe, recommendations for solutions in Poland based on VBHC. Value Based Healthcare (VBHC) is a healthcare financing model developed by M. Porter and E. Teisberg. It is based on the assumptions of financing healthcare providers based on treatment outcomes, that is, values. This concept was created in connection with the constantly growing costs in the American healthcare system, which, however, did not translate into health indicators in the population. The aim of VBHC is to minimize the cost of the system while achieving the best result for the patient. In this model of healthcare organization, it is assumed that those healthcare providers who provide the best quality care should be best financed, thus contributing to cure or significantly improving the quality of life of patients.

CONCLUSIONS. Value Based Healthcare is the recommended method of financing due to the optimization of healthcare expenses while maintaining the appropriate quality of services provided to patients. Currently, many countries in Europe and around the world have started implementing this system solution. However, the transition from a service charge to value for money model is a complex process. In the authors' opinion, the longterm benefits of such a financing model bring a significant improvement in the quality of services and patient satisfaction.
\end{abstract}

Key words: value, health care, health policy, costs, financing

\section{STRESZCZENIE}

CEL PRACY. Celem pracy jest prezentacja założeń koncepcji Value Based Healthcare, związanych z tym korzyści oraz przedstawienie przykładów krajów,

w których koncepcja ta jest wdrażana. W artykule zaproponowano także rozwiązania w oparciu o model VBHC, które mogłyby zostać zaimplementowane w polskim systemie ochrony zdrowia.

MATERIAŁ I METODY. Przeprowadzono przegląd piśmiennictwa za pomocą bazy PubMed via Ovid z zastosowaniem następujących słów kluczowych „,healthcare”, „value-based healthcare”, „,cost”, „economy”, „policy”. Zastosowano następującą strategię: ((value-based healthcare) AND (cost)) AND (value-based 
healthcare[MeSH Terms])) AND (cost[MeSH Terms])) AND (quality)) AND (value)) AND (economy)) AND (economy)) AND (policy)) AND (policy[MeSH Terms]). Uzyskano 72 wyniki. Z tego po analizie abstraktów zakwalifikowano 18 pozycji. Przeanalizowano również pozycje z szarej literatury za pomocą narzędzia Google Scholar oraz inne dokumenty np. Komisji Europejskiej z uwzględnieniem aktualnie dostępnych danych dla Polski i innych krajów. Następnie pracę podzielono na następujące obszary tematyczne: definicje i zasady VBHC, korzyści i wyzwania związane z wdrożeniem modelu, VBHC w Europie, rekomendacje dla rozwiązań w Polsce w oparciu o VBHC.

WYNIKI. Opieka zdrowotna oparta o wartości (ang. Value Based Healthcare, VBHC) to model finansowania opieki zdrowotnej stworzony przez M. Portera i E. Teisberg. Opiera się na założeniach finansowania świadczeniodawców w oparciu o wyniki leczenia, czyli wartości. Koncepcja ta została stworzona w związku ze stale rosnącymi kosztami w amerykańskim systemie ochrony zdrowia, które nie przekładały się jednak na wskaźniki zdrowotne w populacji. Założeniem VBHC jest minimalizacja kosztów systemu przy uzyskaniu najlepszego wyniku dla pacjenta. W tym modelu organizacji ochrony zdrowia, z założenia najlepiej finansowani powinni być ci świadczeniodawcy, którzy dostarczają opieki najlepszej jakości, tym samym przyczyniając się do wyleczenia bądź znacznej poprawy jakości życia pacjentów.

WNIOSKI. Opieka zdrowotna oparta o wartość jest rekomendowanym sposobem finansowania ze względu na optymalizację wydatków na ochronę zdrowia przy zachowaniu odpowiedniej jakości świadczeń udzielanych pacjentom. Obecnie wiele krajów w Europie i na świecie rozpoczęło wdrażanie tego rozwiązania systemowego. Jednak proces przejścia od modelu opłaty za usługi na opłatę za wartość jest procesem złożonym. W opinii autorów długoterminowe korzyści wynikające

z takiego modelu finansowania przynoszą znaczną poprawę jakości świadczeń i satysfakcji pacjentów.

Słowa kluczowe: wartość, opieka zdrowotna, polityka zdrowotna, koszty, finansowanie

\section{INTRODUCTION}

Currently, many European countries struggle with the problem of constantly increasing costs in the healthcare system. This is mainly due to the increase in life expectancy, aging populations, as well as technological advances and the introduction of modern methods of treatment (1). It requires taking actions aimed at limiting the growing costs while maintaining the appropriate quality of services provided to patients. According to OECD data, health expenditure as a percentage of GDP in 2018 averaged $8.8 \%$ (1). A further increase in healthcare expenditure is forecasted in the following years (2). The concept of Value Based Healthcare, i.e. healthcare based on value, assumes a change in the financing and organization of the healthcare system in such a way as to obtain the best health effects in the form of improving the quality of life and health of patients (3) with the efficient allocation of resources.

\section{VALUE BASED HEALTHCARE - DEFINITION}

Value Based Healthcare (VBHC) is a concept proposed in 2006 by M. Porter and E. Teisberg. The theory is based on the following assumptions: basing care organization on cycles of care and disease course, creating value for patients and measuring treatment outcomes as well as costs. The authors of this approach emphasized that the effective implementation of

\section{WSTĘP}

Obecnie wiele krajów europejskich zmaga się z problemem stale rosnących kosztów w systemie ochrony zdrowia. Spowodowane jest to przede wszystkim wydłużaniem średniej długości trwania życia, starzeniem się społeczeństw, a także postępem technologicznym i wprowadzeniem nowoczesnych metod leczenia (1). Wymaga to podjęcia działań mających na celu ograniczenie rosnących kosztów przy jednoczesnym zachowaniu odpowiedniej jakości świadczeń udzielanych pacjentom. Według danych OECD wydatki na zdrowie wyrażone jako procent PKB w 2018 roku wynosiły średnio 8,8\% (1). W kolejnych latach prognozuje się dalszy wzrost nakładów na ochronę zdrowia (2). Koncept Value Based Healthcare, czyli opieki zdrowotnej opartej na wartości zakłada zmianę finansowania i organizacji systemu ochrony zdrowia w taki sposób, by przy efektywnej alokacji zasobów uzyskać jak najlepsze efekty zdrowotne w postaci poprawy jakości życia i stanu zdrowia pacjentów (3).

\section{VALUE BASED HEALTHCARE - DEFINICJA}

Opieka zdrowotna oparta o wartość (ang. Value based healthcare, VBHC) to koncept zaproponowany w 2006 roku przez M. Portera i E. Teisberg. Teoria ta opiera się na następujących założeniach: oparcie organizacji opieki na cyklach opieki i przebiegu schorzenia, tworzeniu wartości dla pacjentów oraz pomiarach 
VBHC is possible thanks to the cooperation of healthcare providers, patients and decision makers. It was supposed to be a response to the rapidly rising costs in the American healthcare system, which, on the other hand, did not translate into improved health outcomes. The value based care model is distinct from capitalization, fee-for-service, or lump sum, in which providers are financed according to the number of services provided. The "value" in this model comes from measuring health outcomes in relation to the cost of achieving them. Value "defines everything that is desirable, worthy and valuable to the individual" (4). According to this definition, the value in relation to healthcare means recovery or a significant improvement in the quality of life of the patient, for which the payer is ready to pay (5). The payment-for-effect approach may significantly contribute to limiting the growing costs of healthcare and lead to the improvement of health indicators of the population $(4,5)$.

\section{PRINCIPLES OF VALUE BASED HEALTHCARE}

The VBHC concept is based on four main pillars. The first pillar is care for achievement of individual patient goals (personal value), the second pillar is achievement of the best results using existing resources (technical value), the third pillar is appropriate distribution of resources between patients (allocative value), and impact of healthcare on society (value social) defines the fourth pillar of VBHC (6).

Stakeholder groups play the most important role in the Value Based Healthcare concept. It is their commitment that is crucial for the proper functioning of the VBHC model. In this concept we distinguish five groups of stakeholders: patients, health providers (doctors, medical personnel and healthcare entities), payers, suppliers (eg. medical equipment), society. wyników i kosztów leczenia. Autorzy tego podejścia podkreślali, że skuteczne wdrożenie VBHC jest możliwe dzięki współpracy świadczeniodawców, pacjentów i decydentów w ochronie zdrowia. Miała to być odpowiedź na rosnące koszty $\mathrm{w}$ amerykańskim systemie ochrony zdrowia, które z drugiej strony nie przekładały się na poprawę efektów zdrowotnych. Model opieki oparty na wartości jest odmienny od kapitacji, opłaty za usługę (ang. fee-for-service) czy ryczałtu, w których świadczeniodawcy są finansowani w zależności od liczby wykonanych świadczeń. „Wartość” w tym modelu wywodzi się z pomiaru wyników zdrowotnych w stosunku do kosztów ich uzyskania. Wartość „określa wszystko, co jest pożądane, godne i cenne dla jednostki” (4). W myśl tej definicji wartość w odniesieniu do ochrony zdrowia oznacza wyzdrowienie bądź istotną poprawę jakości życia pacjenta, za które płatnik jest gotów zapłacić (5). Podejście płatności za efekt może $\mathrm{w}$ istotny sposób przyczynić się do ograniczenia rosnących kosztów opieki zdrowotnej oraz doprowadzić do poprawy wskaźników zdrowotnych populacji $(4,5)$.

\section{ZASADY VALUE BASED HEALTHCARE}

Koncepcja VBHC opiera się na czterech głównych filarach. Pierwszy filar stanowi dbałość o osiągnięcie celów indywidualnych pacjenta (wartość osobista), drugi filar to osiągnięcie najlepszych wyników przy wykorzystaniu istniejących zasobów (wartość techniczna), filar trzeci stanowi odpowiedni podział zasobów między pacjentami (wartość alokacyjna), a wpływ opieki zdrowotnej na społeczeństwo (wartość społeczna) określa czwarty filar VBHC (6).

W koncepcji Value Based Healthcare najważniejszą rolę odgrywają grupy interesariuszy. To ich zaangażowanie ma kluczowe znaczenie dla poprawnego funkcjonowania modelu VBHC. W tej koncepcji wyróżniamy pięć grup interesariuszy: pacjenci, świad-

Table 1 Benefits of VBHC for individual stakeholder groups

Tabela 1 Korzyści wynikające z VBHC dla poszczególnych grup interesariuszy.

\begin{tabular}{|l|l|}
\hline $\begin{array}{l}\text { Stakehoulders/ } \\
\text { Grupa interesariuszy }\end{array}$ & Benefits/ Korzyści \\
\hline Patients/ Pacjenci & Better health outcomes/ Lepsze wyniki zdrowotne \\
\hline Society/ Społeczeństwo & $\begin{array}{l}\text { Better health outcomes/ Lepsze wyniki zdrowotne } \\
\text { Limiting rapid growth of healthcare spending/ } \\
\text { Ograniczenie rosnących wydatków na ochronę zdrowia }\end{array}$ \\
\hline Suppliers/ Dostawcy usług & Adjusting prices to outcome/ Dostosowanie cen do wyników leczenia \\
\hline $\begin{array}{l}\text { Health providers/ } \\
\text { Świadczeniodawcy }\end{array}$ & $\begin{array}{l}\text { Patients'satisfaction/ Większa satysfakcja pacjentów } \\
\text { Efficiency/ Większa efektywność opieki }\end{array}$ \\
\hline Payers/ Płatnicy & $\begin{array}{l}\text { Better cost-control/ Lepsza kontrola kosztów } \\
\text { Risk reduction/ Redukcja ryzyka }\end{array}$ \\
\hline
\end{tabular}

Source: Redefining health care: creating value-based competition on results (8)

Źródło: Opracowanie własne na podstawie Redefining health care: creating value-based competition on results (8) 
Each of these groups benefits from the introduction of value pricing, and they are presented in more detail below (Table I) (8).

One of the most important features of VBHC is competition based on the value of services, i.e. the service provider who healed or significantly improved the health of patients is rewarded. There are several basic principles of value based competition $(9,10)$ :

- Focus on patient values, not cost reduction,

- Competition based on results,

- High quality care at a lower cost,

- Value driven by the healthcare provider's experience in treating the disease entity,

- Competition at the regional and central level, not just local,

- Value based competition results are widely available to healthcare providers, patients and payer,

- Innovations influencing the results awarded by the payer.

The goal of healthcare should be to heal patients, that is, to achieve the value of improved health. The mere pursuit of cost reduction is a false assumption as it does not in any way affect the health outcomes of patients. Cost reduction should be related to the improvement of the quality of care, i.e. an appropriate ratio of costs to effects (4.9), and not cost shifting, limiting benefits or lowering their quality (10).

When measuring the value, the costs of the entire treatment process should be taken into account, not just individual procedures or interventions $(10,11)$. Value and results should be measured meaningfully with respect to the disease (11). Access to information is essential to improving care. Value based competition is beneficial when both healthcare providers, physicians, payers and patients have access to objective and reliable data on treatment outcomes and costs for the entire care cycle (12).

\section{BENEFITS AND CHALLENGES OF IMPLEMENTING VALUE BASED HEALTHCARE}

The VBHC model is viewed positively, many countries are gradually shifting towards value based financing, while the challenges of implementing the concept must be considered. The greatest benefits of VBHC include: 1) reduction of healthcare costs in the long term for the payer in the healthcare system and for the patient (eg lower amounts spent on purchasing drugs); 2) improving the quality of healthcare, including reducing the number of medical advice and medications needed to achieve a positive health outcome; 3) costeffective allocation of resources according to patients' health needs and increasing awareness of system czeniodawcy (lekarze, personel medyczny i podmioty lecznicze), płatnicy, dostawcy usług, społeczeństwo. Każda z tych grup odnosi korzyści związane z wprowadzeniem opłat za wartość, poniżej przedstawiono je bardziej szczegółowo (Tab.I) (7).

Jedną z ważniejszych cech VBHC jest konkurencja oparta na wartości świadczeń tzn. nagradzany jest ten świadczeniodawca, który wyleczył bądź znacznie poprawił stan zdrowia pacjentów. Istnieje kilka podstawowych zasad konkurencji opartej na wartości $(9,10)$ :

- Skupienie na wartościach dla pacjentów, a nie obniżaniu kosztów

- Konkurencja oparta o wyniki

- Wysoka jakość opieki przy niższych kosztach

- Wartość napędzana doświadczeniem świadczeniodawcy w leczeniu danej jednostki chorobowej

- Konkurencja na poziomie regionalnym i centralnym, a nie tylko lokalnym

- Wyniki dot. konkurencji opartej o wartości są powszechnie dostępne dla świadczeniodawców, pacjentów i płatnika

- Innowacje wpływające na wyniki nagradzane przez płatnika

Celem opieki zdrowotnej powinno być wyleczenie pacjentów, czyli osiągnięcie wartości w postaci poprawy stanu zdrowia. Zwykłe dążenie do redukcji kosztów jest błędnym założeniem, bowiem w żaden sposób nie wpływa na wyniki zdrowotne pacjentów. Ograniczenie kosztów powinno być związane z poprawą jakości opieki, czyli odpowiednim stosunkiem nakładów do efektów $(4,9)$, nie zaś przerzucaniem kosztów (cost shifting), ograniczaniem świadczeń czy obniżeniem ich jakości (10). Przy pomiarze wartości należy brać pod uwagę koszty całego procesu leczenia, a nie tylko poszczególnych zabiegów czy interwencji $(10,11)$. Wartość i wyniki powinny być mierzone w sposób znaczący w odniesieniu do schorzenia (11). Kluczowy dla udoskonalania opieki jest dostęp do informacji. Konkurencja oparta na wartości jest korzystna wówczas, gdy zarówno świadczeniodawcy, lekarze, płatnicy i pacjenci mają dostęp do obiektywnych i rzetelnych danych dotyczących wyników leczenia oraz kosztów dla całego cyklu opieki (12).

\section{KORZYŚCI I WYZWANIA ZWIĄZANE Z WDROŻENIEM VALUE BASED HEALTHCARE}

Model VBHC jest oceniany pozytywnie, wiele krajów stopniowo przechodzi na finansowanie oparte o wartość, natomiast należy wziąć pod uwagę wyzwania związane z wdrożeniem tej koncepcji. Do największych korzyści VBHC należy zaliczyć: 1) ograniczenie kosztów opieki zdrowotnej w długim okresie dla płatnika w systemie ochrony zdrowia, jak i dla pacjenta 
resources; 4) using them in accordance with scientific evidence $(6,12)$. There is also criticism of this model in the literature. It is emphasized that focusing on cost control may negatively affect patients' trust in doctors and the treatment process (13). It is also noted that VBHC does not offer a methodology for implementing process improvement initiatives (14). The challenges related to the introduction of VBHC are also associated with organizational and financial aspects, such as a short-term increase in costs related to the VBHC implementation process, especially in the area of creating extensive registers of data collection in healthcare, resistance from healthcare providers to the introduction of a new systemic solution, or the need for large expenditure work necessary to create standards for measuring results. It is also problematic to define values in relation to the patient, payer and service provider (15). This requires ensuring broad inter-sectoral coordination and coordination between experts in various fields, including public health, management, economics and policy makers $(16,17)$.

\section{VALUE BASED HEALTHCARE IN EUROPE}

Healthcare decision-makers see the need to better use their resources and reduce costs while ensuring the best, universally available healthcare, which is possible through the implementation of $\mathrm{VBHC}$ tools. Adaptation of the entire VBHC concept as a universal mechanism to be implemented in Europe is complicated, due to the fact that in collecting health data, in the adopted payment mechanisms, or in the organization of the health insurance system (18). It should be noted that the individual components of VBHC, e.g. health technology assessment (HTA) by the agencies created for this, have been functioning in European systems for years (19). The implementation of the VBHC idea in European countries takes place in various ways. In the Netherlands and Sweden, the process takes place at national level, while in France it is often a grassroots initiative of institutions. Countries indicate differences in the level of preparation for introducing value based care (Table II). Scandinavian countries and the Netherlands show a greater cook. In the case of Germany, Poland or Spain, there are solutions that partially fit into the VBHC idea and enable the process of its adaptation. (np. mniejsze kwoty przeznaczane na zakup leków); 2) poprawa jakości opieki zdrowotnej, w tym zmniejszenie liczby potrzebnych porad lekarskich oraz leków do osiągnięcia pozytywnego wyniku zdrowotnego; 3) efektywna kosztowo alokacja środków, zgodnie z potrzebami zdrowotnymi pacjentów i zwiększenie świadomości na temat posiadanych zasobów systemowych; 4) korzystanie $z$ nich zgodnie $z$ dowodami naukowymi $(6,12)$. W literaturze można znaleźć też krytykę takiego modelu. Podkreśla się, że skupianie na kontroli kosztów może negatywnie wpływać na zaufanie pacjentów do lekarzy i procesu leczenia (13). Zwraca się również uwagę, że VBHC nie oferuje metodologii wdrażania inicjatyw usprawniających procesy(14). Wyzwania związane z wprowadzeniem VBHC wiążą się także $z$ aspektami organizacyjno-finansowymi, jak krótkotrwały wzrost kosztów związany z procesem wdrażania VBHC, zwłaszcza w obszarze tworzenia obszernych rejestrów gromadzenia danych $\mathrm{w}$ opiece zdrowotnej, opór ze strony świadczeniodawców przed wprowadzeniem nowego rozwiązania systemowego, czy potrzeba dużych nakładów pracy niezbędnych do stworzenia standardów pomiarów wyników. Problematyczne jest również zdefiniowanie wartości w odniesieniu do pacjenta, płatnika i świadczeniodawcy (15). Wymaga to zapewniania szerokiej koordynacji międzysektorowej i między ekspertami z rożnych dziedzin (m.in. z obszaru zdrowia, zarządzania, ekonomii) oraz decydentów $(16,17)$.

\section{VALUE BASED HEALTHCARE W EUROPIE}

Decydenci w ochronie zdrowia dostrzegają potrzebę lepszego wykorzystania posiadanych zasobów i ograniczenia kosztów przy zapewnieniu jak najlepszej, powszechnie dostępnej opieki zdrowotnej, co jest możliwe przez implementację narzędzi VBHC. Adaptacja całej koncepcji VBHC jako uniwersalnego mechanizmu do wdrożenia w Europie jest skomplikowana, wynika to $\mathrm{z}$ faktu dużego zróżnicowania m.in. w gromadzeniu danych zdrowotnych, w przyjętych mechanizmach płacenia, czy organizacji systemu ubezpieczeń zdrowotnych (18). Należy zaznaczyć, że poszczególne składowe VBHC, np.: ocena technologii medycznych (health technology assesment, HTA) przez stworzone do tego agencje od lat funkcjonują $\mathrm{w}$ systemach europejskich (19). Wprowadzanie idei VBHC w krajach Europy odbywa się w różny sposób. W Holandii i Szwecji proces ten odbywa się na poziomie krajowym, we Francji natomiast jest często oddolną inicjatywą instytucji. Kraje wskazują różnice w poziomie przygotowania do wprowadzenia opieki opartej na wartości (Tab. II). Większą gotować wykazują państwa skandynawskie oraz Holandia. W przypadku Niemiec, Polski czy Hiszpanii istnie- 
Table 2. The level of preparation for the implementation of VBHC in selected European Union countries - examples of evaluation indicators

Tabela 2. Poziom przygotowania do wdrożenia VBHC w wybranych krajach Unii Europejskiej - przykładowe wskaźniki oceny.

\begin{tabular}{|c|c|c|c|c|c|c|}
\hline \multirow[b]{2}{*}{$\begin{array}{l}\text { Selected assessment indicator/ } \\
\text { Wybrane wskaźniki oceny }\end{array}$} & \multirow{2}{*}{$\begin{array}{l}\text { Rating } \\
\text { scale/ } \\
\text { Skala } \\
\text { oceny }\end{array}$} & \multicolumn{5}{|c|}{ Country/ Kraje Unii Europejskiej } \\
\hline & & $\begin{array}{l}\text { Germany/ } \\
\text { Niemcy }\end{array}$ & $\begin{array}{c}\text { The } \\
\text { Netherlands/ } \\
\text { Holandia }\end{array}$ & $\begin{array}{l}\text { Poland/ } \\
\text { Polska }\end{array}$ & $\begin{array}{l}\text { Spain/ } \\
\text { Hiszpania }\end{array}$ & $\begin{array}{l}\text { Sweden/ } \\
\text { Szwecja }\end{array}$ \\
\hline \multicolumn{7}{|c|}{$\begin{array}{l}\text { Context, policy and institutions enabling implementation of VBHC/ } \\
\text { Kontekst, polityka i instytucje umożliwiające wdrożenie VBHC }\end{array}$} \\
\hline $\begin{array}{l}\text { Population covered/ } \\
\text { Populacja objęta ubezpieczeniem } \\
\text { zdrowotnym }\end{array}$ & $0-4$ & 4 & 4 & 4 & 4 & 4 \\
\hline $\begin{array}{l}\text { VBHC implementation components } \\
\text { (quality standards, payment } \\
\text { mechanisms, result-based care)/ } \\
\text { Elementy umożliwiające wdrożenie } \\
\text { VBHC (standardy jakości, } \\
\text { mechanizmy płacenia, opieka oparta } \\
\text { na wyniku) }\end{array}$ & $0-3$ & 3 & 3 & 2 & 1 & 3 \\
\hline $\begin{array}{l}\text { VBHC training/ } \\
\text { Kształcenie i szkolenie z zakresu } \\
\text { VBHC }\end{array}$ & $0-2$ & 0 & 1 & $\mathbf{0}$ & 0 & 0 \\
\hline $\begin{array}{l}\text { Independent HTA institution/ } \\
\text { Niezależna Instytucja oceny HTA }\end{array}$ & $0-2$ & 2 & 2 & 2 & 2 & 2 \\
\hline $\begin{array}{l}\text { Guidelines for evidence-based } \\
\text { healthcare/ } \\
\text { Wytyczne dla opieki zdrowotnej } \\
\text { opartej na dowodach }\end{array}$ & $0-4$ & 3 & 3 & 2 & 2 & 4 \\
\hline \multicolumn{7}{|c|}{ Cost and outcome measurement/ Pomiar wyników i kosztów } \\
\hline $\begin{array}{l}\text { National disease reigster/ } \\
\text { Krajowy rejestr chorób }\end{array}$ & $0-4$ & 2 & 3 & 2 & 2 & 4 \\
\hline $\begin{array}{l}\text { Standardization of patient outcomes } \\
\text { data/ } \\
\text { Standaryzacja danych wyników } \\
\text { pacjentów }\end{array}$ & $0-2$ & 1 & 1 & 1 & 1 & 2 \\
\hline $\begin{array}{l}\text { Data on costs of treatment/ } \\
\text { Dane na temat kosztów leczenia }\end{array}$ & $0-3$ & 3 & 2 & 2 & 2 & 3 \\
\hline \multicolumn{7}{|c|}{ Integrated care/ patient-centered care/ Opieka zintegrowana i skoncentrowana na pacjenta } \\
\hline $\begin{array}{l}\text { National policy supporting intergrated } \\
\text { care / patient-centered care/ } \\
\text { Polityka krajowa wspierająca opiekę } \\
\text { zintegrowaną i/lub skoncentrowaną na } \\
\text { pacjencie }\end{array}$ & $\begin{array}{l}\mathrm{Y} / \mathrm{N} / \\
\mathrm{T} / \mathrm{N}\end{array}$ & $\mathrm{NO} / \mathrm{NIE}$ & YES/ TAK & YES & $\mathrm{NO} / \mathrm{NIE}$ & YES/ TAK \\
\hline $\begin{array}{l}\text { Long-term treatment focus/ } \\
\text { Skupienie na długofalowej ścieżce } \\
\text { leczenia }\end{array}$ & $0-2$ & 1 & 0 & 1 & 2 & 2 \\
\hline \multicolumn{7}{|c|}{ Outcome based payment/ Platność oparta na wyniku } \\
\hline $\begin{array}{l}\text { Payer supports package payments/ } \\
\text { Płatnik wspiera płatności pakietowe }\end{array}$ & $0-3$ & 3 & 2 & 2 & 1 & 3 \\
\hline $\begin{array}{l}\text { Mechanism for identifying therapeutic } \\
\text { interventions for recall/ } \\
\text { Mechanizm identyfikacji interwencji } \\
\text { leczniczych do wycofania }\end{array}$ & $\begin{array}{l}\mathrm{Y} / \mathrm{N} / \\
\mathrm{T} / \mathrm{N}\end{array}$ & YES/ TAK & YES/ TAK & YES/ TAK & $\mathrm{NO} / \mathrm{NIE}$ & YES/ TAK \\
\hline
\end{tabular}

Source: Value-based healthcare: A global assessment (21)

Źródło: Value-based healthcare: A global assessment (21) 
According to the available data, 25 countries (including Germany, the United States, Japan, the Netherlands, Sweden) around the world have started the process of implementing solutions based on health outcomes that can be associated with the idea of Value Based Healthcare (21). In Europe, Sweden is the leader in reorganizing the system towards value based care $(22,23)$. The extensive system of medical registers had a significant impact on the progress in the implementation of VBHC in Sweden, in 2010 there were more than 70 registers collecting health data for over $85 \%$ of patients (21). In Sweden, in 2013, the SVEUS platform was created - a nationwide cooperation program for outcome-based reimbursement and monitoring of healthcare that covers $70 \%$ of the country's population in eight therapeutic areas (22). The aim of the program is to improve public health, use resources more efficiently, better quality of care, and increase awareness of different patient groups at local level and nationwide. Using extensive medical registers and detailed evidence-based guidelines for healthcare, the platform was equipped with a tool to analyze the treatment process and its results in order to identify areas for improvement. SVEUS allows you to constantly monitor the characteristics of patient groups, the treatment process and associated costs, as well as treatment results, while being a platform for managing the reimbursement process. The Swedish system also introduced changes in the method of reimbursement, in line with the assumptions of VBHC, including package payments in the Stockholm district, which three years after the introduction of the hip and knee joint prosthesis resulted in a $26 \%$ reduction in the risk of complications and a $20 \%$ reduction in costs while the waiting time for surgery was reduced by $23 \%(24.25)$.

\section{RECOMMENDATIONS FOR THE INTRODUCTION OF VALUE BASED HEALTHCARE IN POLAND}

One of the basic challenges faced by the healthcare system in Poland is the aging of the population (26). Another is the availability of healthcare services - in the second quarter of $2019,66 \%$ of complaints to the National Health Fund related to the availability of services (27). The introduction of the VBHC-based model, in authors' opinion, may contribute to the improvement of the quality and availability of services in the Polish system.

1. The basis for introducing VBHC should be a change in the perception of health as not only the absence of disease or ailment. Health is an investment that translates into all aspects of life, including economic development. ją rozwiązania częściowo wpisujące się w ideę VBHC i umożliwiające proces jej adaptacji.

Według dostępnych danych 25 krajów (m.in. Niemcy, Stany Zjednoczone, Japonia, Holandia, Szwecja) na świecie rozpoczęło proces wdrażania rozwiązań opartych na wyniku zdrowotnym, które można powiązać z ideą Value Based Healthcare (21). W Europie państwem będącym liderem $\mathrm{w}$ reorganizacji systemu w kierunku opieki opartej na wartości jest Szwecja $(22,23)$. Znaczny wpływ na postęp we wdrażaniu VBHC w Szwecji miał rozbudowany system rejestrów medycznych, w 2010 roku prowadzonych było ponad 70 rejestrów gromadzących dane zdrowotne o ponad 85\% pacjentów (21). W Szwecji w 2013 roku stworzona została platforma SVEUS - ogólnokrajowy program współpracy na rzecz refundacji opartej na wyniku i monitorowania opieki zdrowotnej, zasięgiem obejmujący $70 \%$ populacji kraju w ośmiu obszarach terapeutycznych (22). Celem programu jest poprawa zdrowia społeczeństwa, efektywniejsze korzystanie z zasobów, lepsza jakość opieki oraz zwiększenie wiedzy na temat różnych grup pacjentów na poziomie lokalnym i ogólnokrajowym. Korzystając z obszernych rejestrów medycznych oraz szczegółowych wytycznych opartych na dowodach (evidence based guidelines for healthcare) platforma została wyposażona w narzędzie analizujące proces leczniczy i jego wyniki w celu określenia obszarów wymagających poprawy. SVEUS pozwala na stałe monitorowanie charakterystyki grup pacjentów, procesu leczenia i kosztów z nim związanych oraz wyników leczenia, jednocześnie będąc platformą do zarządzania procesem refundacji. W szwedzkim systemie wprowadzono również zmiany w sposobie refundacji, wpisujące się w założenia VBHC, przyjęto między innymi płatności pakietowe w okręgu Sztokholmskim, które trzy lata od wprowadzenia w świadczeniu protezy stawowej biodra i kolana wpłynęły na zmniejszenie o 26\% ryzyka powikłań i $20 \%$ redukcję kosztów przy skróceniu czasu oczekiwania na operację o $23 \%(24,25)$.

\section{REKOMENDACJE DLA WPROWADZENIA VALUE BASED HEALTHCARE W POLSCE}

Jednym z podstawowych wyzwań, przed którym stoi system ochrony zdrowia w Polsce jest starzenie się społeczeństwa (26). Kolejnym jest dostępność świadczeń opieki zdrowotnej - w II kwartale 2019 roku 66\% skarg kierowanych do Narodowego Funduszu Zdrowia dotyczyło dostępności świadczeń (27). Wprowadzenie modelu opartego o VBHC w opinii autorów może przyczynić się do poprawy jakości i dostępności świadczeń w polskim systemie.

1. Podstawą wprowadzenia VBHC powinna być zmiana postrzegania zdrowia, jako nie tylko braku 
2. The implementation of VBHC should be based on a long-term strategy. It is recommended to gradually introduce the individual components of the concept. The basis for building a new model of organization is the analysis of data on the available infrastructure and human resources, taking into account the forecasts of changes and determining the degree of adequacy of the services provided to the health needs of the society. Standardized outcomes that are relevant to patients, such as improving the quality of care by reducing the incidence of adverse events, should be defined and identified.

3. It is important to create reliable medical registers. The purpose of such registers is to provide the information necessary to develop and improve operating procedures in order to obtain the best result.

4. Maintaining an open dialogue with patients. Beneficiaries are one of the stakeholder groups in the VBHC scheme, alongside the payer and service provider. The patient's perspective is an important component necessary to assess the quality of healthcare.

5. Competition of service providers should be based on the cure rate of patients in the given disease entities.

6. Introduction of new payment methods adapted to the principles of $\mathrm{VBHC}$, such as package or pay-for-performance (P4P) payments, which are based on the full cycle of healthcare (prevention, diagnosis, treatment, rehabilitation).

\section{CONCLUSIONS}

Changing from a service pricing model to a value pricing system is a time consuming and complex process. In the first step of changing funding, shortterm healthcare costs may increase, which may slow down the transition to value-for-money. However, taking into account long-term costs, this solution seems to be the most beneficial, both from the perspective of the payer, service providers and patients. The progressive reduction of costs and better quality of patient care are the main goals of the pay-for-value system. The long-term effect of these actions should be the improvement of health indicators in the population. At present, actions are being taken in Poland to shift the orientation of the system to the patient, such as the introduction of coordinated healthcare, or work on new mechanisms for reimbursement of benefits carried out at AOTMiT. choroby czy niedomagania. Zdrowie jest inwestycją, która przekłada się na wszystkie aspekty życia, w tym rozwój gospodarki.

2. Wdrożenie VBHC powinno opierać się na długoterminowej strategii. Zalecane jest stopniowe wprowadzanie poszczególnych składowych koncepcji. Podstawą budowania nowego modelu organizacji jest analiza danych na temat posiadanych zasobów infrastruktury $\mathrm{i}$ kadr, $\mathrm{z}$ uwzględnieniem prognoz zmian oraz określenie stopnia adekwatności udzielanych świadczeń do potrzeb zdrowotnych społeczeństwa. Należy zdefiniować i określić wystandaryzowane wyniki, które są istotne dla pacjentów, jak np.: poprawa jakości opieki przez zmniejszenie występowania zdarzeń niepożądanych.

3. Istotne jest tworzenie rzetelnych rejestrów medycznych. Celem takich rejestrów jest dostarczenie informacji niezbędnych do opracowania i doskonalenia procedur postępowania w celu uzyskania najlepszego wyniku.

4. Prowadzenie otwartego dialogu $\mathrm{z}$ pacjentami. Świadczeniobiorcy są jedną z grup interesariuszy w schemacie działania VBHC, obok płatnika czy świadczeniodawcy. Pespektywa pacjenta jest istotną składową niezbędną do oceny poziomu jakości opieki zdrowotnej.

5. Konkurencja świadczeniodawców powinna być oparta o wskaźnik wyleczenia pacjentów w danych jednostkach chorobowych.

6. Wprowadzenie nowych metod płatności dostosowanych do zasad VBHC, jak płatności pakietowe czy pay-for-performance (P4P), które bazują na pełnym cyklu opieki zdrowotnej (prewencja, diagnostyka, leczenie, rehabilitacja).

\section{WNIOSKI}

Zmiana modelu opłat za usługi na system opłat za wartość jest procesem czasochłonnym i skomplikowanym. W pierwszym etapie zmiany sposobu finansowania mogą wzrosnąć krótkoterminowe koszty w opiece zdrowotnej, co może być przyczyną zahamowania procesu przejścia na opłaty za wartość. Jednak biorąc pod uwagę koszty długoterminowe, takie rozwiązanie wydaje się być najbardziej korzystne, zarówno z perspektywy płatnika, świadczeniodawców, jak i pacjentów. Stopniowe obniżanie kosztów oraz lepsza jakość opieki nad pacjentami to główne cele systemu opartego na płatności za wartość. Długoterminowym skutkiem tych działań powinna być poprawa wskaźników zdrowotnych w populacji. Obecnie w Polsce podejmowane są działania zmierzające do przesunięcia orientacji systemu na pacjenta, jak wprowadzanie koordynowanej opieki zdrowotnej, czy prowadzone w AOTMiT prace nad nowymi mechanizmami refundacji świadczeń. 


\section{REFERENCES}

1. https://www.oecd.org/health/health-expenditure. $\mathrm{htm}[10.06 .2020]$

2. https://www.who.int/health_financing/documents/ health-expenditure-report-2019.pdf?ua=1 [11.06.2020]

3. Porter M.E. A strategy for health care reform-toward a value-based system. N Engl J Med. 2009;361(2):109-112.

4. Encyklopedia PWN, https://encyklopedia.pwn.pl/ [dostęp z 12.05.2020]

5. Nowa definicja ochrony zdrowia i jej wpływ na poprawę jakości leczenia. Raport otwarcia Value Based Healthcare, Nojszewska E., Walewski J. (red.), Warszawa 2019, 14-18.

6. Path-Theta Collaboration. Optimizing chronic disease management mega-analysis: economic evaluation. Ont Health Technol Assess Ser. 2013;13(13):1-148.

7. European Commission. Defining Value In "Value based Healthcare", Report of the Expert Panel on effective ways of investing in Health (EXPH). ISBN 978-92-76-08993-3, European Union, 2019

8. Porter M.E., Teisberg E.O., Redefining health care: creating value-based competition on results, Boston: Harvard Business School Press, 2006; 98-111.

9. MedTechEurope, B.C.G.B.a., Procurement: the Unexpected Driver of Value-Based Health Care, 2015.

10. Srivastava D, Mueller M, Hewlett E. Better ways to pay for health care., Paris 2016

11. Porter M, Teisberg E., How physicians can change the future of health care. JAMA. 2007;297(10):1103-1111.

12. Burnham JM, Meta F, Lizzio V, Makhni EC, Bozic KJ. Technology assessment and cost-effectiveness in orthopedics: how to measure outcomes and deliver value in a constantly changing healthcare environment. Curr Rev Musculoskelet Med. 2017;10(2):233-239.

13. Groenewoud, A.S., Westert, G.P. \& Kremer, J.A.M. Value based competition in health care's ethical drawbacks and the need for a values-driven approach. BMC Health Serv Res 19. 2019; 256

14. Zipfel, N., van der Nat, P.B., Rensing, B.J.W.M. et al. The implementation of change model adds value to value-based healthcare: a qualitative study. BMC Health Serv Res 19.2019; 643

15. Manner PA. Guest Editorial: Is There Value in Value-based Health Care?. Clin Orthop Relat Res. 2019;477(2):265-267.

16. Lomas J, Claxton K, Martin S, Soares M. Resolving the "Cost-Effective but Unaffordable" Paradox: Estimating the Health Opportunity Costs of Nonmarginal Budget Impacts. Value Health. 2018;21(3):266-275.
17. Value in healthcare. Mobilizing cooperation for health system transformation. World Economic Forum, http://www3.weforum.org/docs/WEF Value_Healthcare_report_2018.pdf [12.06.2020]

18. Stempsey, W., Disease and diagnosis: Valuedependent realism. Vol. 63, ed. S.S.B. Media 2006

19. Fendrick AM, Chernew ME. Value-based insurance design: a "clinically sensitive" approach to preserve quality of care and contain costs. Am J Manag Care. 2006;12(1):18-20.

20. An introduction to value-based healthcare in Europe. The Economist Intelligent Unit 2015. http://vbhcprize.com/wp-content/uploads/2014/03/ An-introduction-to-value-based-healthcare-inEurope.pdf [01.06.2020]

21. Charlesworth A, Davies A, Dixon J. Reforming payment for health care in Europe to achieve better value. Research report. Nuffield Trust 2012.

22. Value-based healthcare: A global assessment. A report from The Economist intelligence Unit 2016. https://eiuperspectives.economist.com/ sites/default/files/EIU_Medtronic_Findings-andMethodology_1.pdf [01.06.2020]

23. Larsson S, Lawyer P, Silverstein M. From Concept to Reality. Putting Value-Based Health Care into Practice in Sweden. The Boston Consulting Group 2010. https://www.bcg.com/documents/file64538. pdf [01.06.2020]

24. https://eiuperspectives.economist.com/sites/ default/files/value-basedhealthcareinswedenreach ingthenextlevel.pdf [26.05.2020]

25. Wohlin J. Effects of introducing bundled payment and patients' choice of provider for elective hip and knee replacement in Stockholm county Karolinska Institutet 2017

26. Putera I. Redefining Health: Implication for ValueBased Healthcare Reform. Cureus. 2017;9(3):e1067.

27. Ageing Europe, Looking at the lives of older people in the EU., Luxembourg: Publications Office of the European Union, 2020

28. https://www.nfz.gov.pl/o-nfz/skargi-i-wnioski/ [29.01.2021]

Received: $3.12 .2020 \mathrm{r}$.

Accepted for publication: 10.02 .2021

Otrzymano: 3.12.2020 r.

Zaakceptowano do publikacji: 10.02.2021 r.

\section{Address for correspondence: Adres do korespondencji:}

Olga Partyka

National Institute of Public Health - National Institute of Hygiene, Department of System and Economic Analyzes, ul. Chocimska 24, 00-791 Warszawa phone (+48) 225421295 